Ambiente \& Água - An Interdisciplinary Journal of Applied Science
ISSN 1980-993X - doi:10.4136/1980-993X
www.ambi-agua.net
E-mail: ambi.agua@gmail.com

\title{
Technical contributions to territorial planning and the use of ecosystemic services in a hydrographic basin with a water deficit in the Atlantic Rainforest of Brazil
}

\author{
ARTICLES doi:10.4136/ambi-agua.2296
}

Received: 27 Jun. 2018; Accepted: 11 Jan. 2019

\author{
Douglas Leite Figueira ${ }^{(\mathbb{D})}$; Ricardo Valcarcel ${ }^{D}$; Marcelle Nardelli Baptista* \\ Universidade Federal Rural do Rio de Janeiro (UFRRJ), Seropédica, RJ, Brasil \\ Instituto Florestas (IF). Departamento de Ciências Ambientais (DCA). \\ E-mail: douglas_nf@hotmail.com,ricardo.valcarcel@gmail.com,marcellenardelli@gmail.com \\ *Corresponding author
}

\begin{abstract}
The catchment basin of the Dois Rios River (R2R) $\left(3159 \mathrm{~km}^{2}\right)$ unites the climatic and environmental effects typical of areas located on the leeward side of mountain chains. It has a deficient water balance, with sparse and very specific wet areas. This study identifies delimitation areas, and characterizes and groups those basins and floodplains which show the greatest capacity for producing ecosystemic services related to maintaining the continuity of water resources in the $\mathrm{R} 2 \mathrm{R}$ basin. Locations with higher pluviometric indices (1500 to $2800 \mathrm{~mm} /$ year) were selected and grouped into micro basins with the highest potential for capturing rainfall due to their being on the leeward side of the mountains in the region (with their slopes oriented to permit them to capture humidity and concave plane curvature). The 42 basins formed 4 groups, from which the 17 micro basins with the highest probability of providing ecosystemic services were chosen, belonging to Groups III and IV. Within these groups, the 498 floodplains with the highest potential for offering ecosystemic services (Group D) present the greatest capacity for water retention and sustainable effects (high average circularity index, higher altitudes and low occupation rates). The correct use of $0.0006 \%$ of the basin can guarantee the direct flow of the drainage for the entire basin. This strategy only requires renaturation measures, discipline with regard to the land uses and strict observance of the processes which generate ecosystemic services in the floodplains of these basins, resulting in relevant socio-environmental benefits for all socioeconomic segments within the R2R basin.
\end{abstract}

Keywords: floodplain, planning, water regulation.

\section{Subsídio para ordenamento territorial e aproveitamento de serviços ecossistêmicos em bacia hidrográfica com déficit hídrico na Mata Atlântica}

\section{RESUMO}

A bacia do rio Dois Rios (R2R) $\left(3.159 \mathrm{~km}^{2}\right)$ recolhe os efeitos climáticos e ambientais típicos de zonas situadas a sotavento de cadeias montanhosas. Tem balanço hídrico deficitário, havendo poucos e específicos locais úmidos. Este estudo identifica, espacializa, caracteriza e agrupa as planícies de inundação com maior habilidade em produzir serviços ecossistêmicos 
relacionados à perenidade de recursos hídricos na bacia R2R. Foram segregados locais com maiores índices pluviométrico (1500 a $2800 \mathrm{~mm} / \mathrm{ano}$ ), agrupados em microbacias com maior potencial de captação em função de estarem a sota-vento na região (slopes oriented to permit them to capture humidity and concave plane curvature). As 42 bacias formaram 4 grupos, onde levantou-se 17 microbacias com alto potencial de fornecer serviços ecossistêmicos pertencentes aos Grupos III e IV. Nestes grupos, 498 planícies de inundação com maior potencial de oferta de serviços ecossistêmicos (grupo D) apresentam habilidades para retenção hídrica e efeitos de perenização (high average circularity index, higher altitudes and low occupation rates). O uso correto de $0,0006 \%$ pode garantir o escoamento direto das drenagens de toda a bacia. Está estratégica implicaria em medidas de renaturalização, disciplinamento dos usos e estrita observação dos processos que geram serviços ecossistêmicos nas planícies das bacias, trazendo relevantes benefícios socioeconômicos para todos os segmentos da bacia do R2R.

Palavras-chave: planejamento, planície de inundação, regulação hídrica.

\section{INTRODUCTION}

Floodplains are the first areas to be saturated after intense precipitation and the overflow of river channels in hydrographic basins (Baptista et al., 2014). They accumulate water and gradually release it into channels, filling up with a backflow (Baptista et al., 2017). The ecosystemic services related to water production permit the survival of these ecosystems, in which humans are an integral and inseparable part and are directly benefited. Among the relevant hydrological ecosystemic services are water regularization, lamination of flooding and amplification of the minimum flows during dry periods (Baptista et al., 2017). The conservation of wet areas in the floodplains is considered to be more efficient from the hydrological point of view, and more economical than the construction of large reservoirs (Baptista and Valcarcel, 2018) when the principles of sustainable development prevail.

Steeply sloping regions which are blocked from the direct influence of humid winds by mountain chains present specific environmental constraints and require objective planning strategies in order to achieve sustainability, especially those areas with a potential for water storage, such as floodplains. Headwaters present characteristics such as precipitation, sizes and forms of floodplains which are distinct from the rest of the catchment basin, affecting the hydric performance of lower areas. In this upper section of the basin, drainage patterns are particularly rectilinear, with fewer contributions from upstream and lower retention capacity, with fast flows and less lateral connection between the channel and the floodplains.

Floodplains are distinguished by their capacity to store water in "flood buffering basins", which reduce the discharge from the headwaters, thus affecting the potential for flooding during rainfall and the contribution from the basic flow afterwards (Reinhardt et al., 2011). The drainage coefficient can be variable in small basins which contribute to the direct runoff (both surface and sub-surface) in catchment basins with low storage capacity (Oswald et al., 2011), as well as the basic flow in catchment basins with high storage capacity.

Decentralized measures for administering the hydrographic basins of rivers may be efficient strategies for managing floods, water retention and recharging of the aquifers (Reinhardt et al., 2011). Being open systems, they join the combined effects of characteristics such as the surface area, the circularity index, the plane of the curve of the slope and the orientation of the slopes in relation to the humid winds (windward slopes) which interfere in the micro basins (Cardoso et al., 2006) and extrapolate the products to the larger catchment basins, influencing the dynamics of water capture and transmission from the slopes to the floodplains, where that water will be stored. 
The Dois Rios River Basin $\left(3159 \mathrm{~km}^{2}\right)$ is located on the right bank $\left(14,165 \mathrm{~km}^{2}\right)$ of the Paraíba do Sul River (total catchment area 55,400 $\mathrm{km}^{2}$ ), has a gradient of $2348 \mathrm{~m}$ and receives the climatic and environmental effects typical of sheltered areas, situated on the leeward slopes of the Serra do Mar Mountains. Its water balance is predominantly deficient, with few and specific wet areas, determined by the aerial basins, vertical precipitation and horizontal interception (dew, mist and other hidden precipitation). The region has a strong agricultural presence with high production, which leads to high water consumption. This study identifies, delimitation areas, characterizes and groups the floodplains with the highest capacity for producing ecosystemic services related to maintaining constant water resources in the R2R catchment basin for the purpose of the sustainable management of those resources.

\section{MATERIALS AND METHODS}

\subsection{Study Area}

The slopes and channels of the Paraiba do Sul River catchment basin $\left(55,400 \mathrm{~km}^{2}\right)$ have their orientation and shape conditioned by the geological limits of the Serra da Mantiqueira Mountains on the left side and the Serra do Mar Mountains on the right side of the main channel. Its headwaters in the region of Guararema, in the Brazilian state of São Paulo, present a reduction in declivity, which decreases from $4.9 \mathrm{~m} / \mathrm{km}$ to $0.19 \mathrm{~m} / \mathrm{km}$. This configuration of the relief conditions the drainage pattern and the formation of floodplains.

The left bank features a high plateau on top of the mountains and gentler slopes which, associated with the topographic divisions far from the channels, form the relief with reduced steepness, similar to the regions known as "oceans of hills". The extensive rivers are nestled in the valleys that separate these hills from the high plateaus of the southern portion of Minas Gerais state, where they receive the climatic influence of the sea, in spite of the distance and the interference of the Serra do Mar Mountains.

The right bank has a few low plateaus and presents a sharper relief, with steep cliffs and small valleys. Even though it is closer to the sea, it receives less influence from the moist winds because it is sheltered, which justifies the predominance of a generalized water deficit, most accentuated in the middle and lower stretches of the Paraiba do Sul catchment basin. In this region, the lack of water and the low capacity for supporting ecosystems confer less resilience, with an increase in erosive processes. In these areas, $50 \%$ of the territory presents high to very high vulnerability to erosion (AGEVAP, 2006).

The R2R catchment basin $\left(3159 \mathrm{~km}^{2}\right)$ is located on the right bank of the Paraiba do Sul River (Figure 1). It is formed by the Negro River and the Grande River, and has a predominantly ENE orientation. The entrance of moist air masses is descending due to the orientation and orography. The circulation of humid air masses immediately downstream of the interfluvial areas alters the saturation of atmospheric humidity and creates zones with different levels of humidity, conditioning the ecological diversity and offer of environmental attributes (Barboza et al., 2015).

The high-altitude tropical climate $(\mathrm{Cf})$ and subtropical climate $(\mathrm{Cw})$, according to Köppen's classification, have an average annual rainfall of $1500 \mathrm{~mm}$ and average annual temperature of $17.8^{\circ} \mathrm{C}$ (average in winter of $9^{\circ} \mathrm{C}$; average in summer of $28^{\circ} \mathrm{C}$ ). The vegetation in this catchment basin was originally composed of Dense Ombrophilous Mountain Forest and Semi Deciduous Broadleaved Forest of the Atlantic Rainforest biome (IBGE, 2012).

The Serra do Mar mountain chain affects the water balance of the catchment basin, with the discharge from the moist winds occurring on the slopes of Cachoeiras de Macacu, on the windward side of these mountains. The majority of the hidden precipitation in the zones located on the leeward side occurs at points near gorges, where the passage of humid air masses is concentrated (Cortines et al., 2011) and where the vegetation is able to reinforce the maximum 
horizontal interception. These points and the neighboring steep slopes, more exposed to these humid winds, are the most important locations for recharging the soil with water (Barboza et al., 2015). In these mountainous cliffs, the average annual rainfall is $2700 \mathrm{~mm}$, due to the orography which contrasts with the high plateau beyond the Serra do Mar Mountains, where the average humidity is less than $1100 \mathrm{~mm}$ per year (CPRM, 2001). The altitude of the catchment basin reaches 2366 meters at the peaks and drops to 12 meters at the mouth. The direction in which the drainage networks are oriented is influenced by the geology of the reactivated faults of the Mesozoic separation and the consequent subdivision of the Gondwana supercontinent (AGEVAP, 2006).

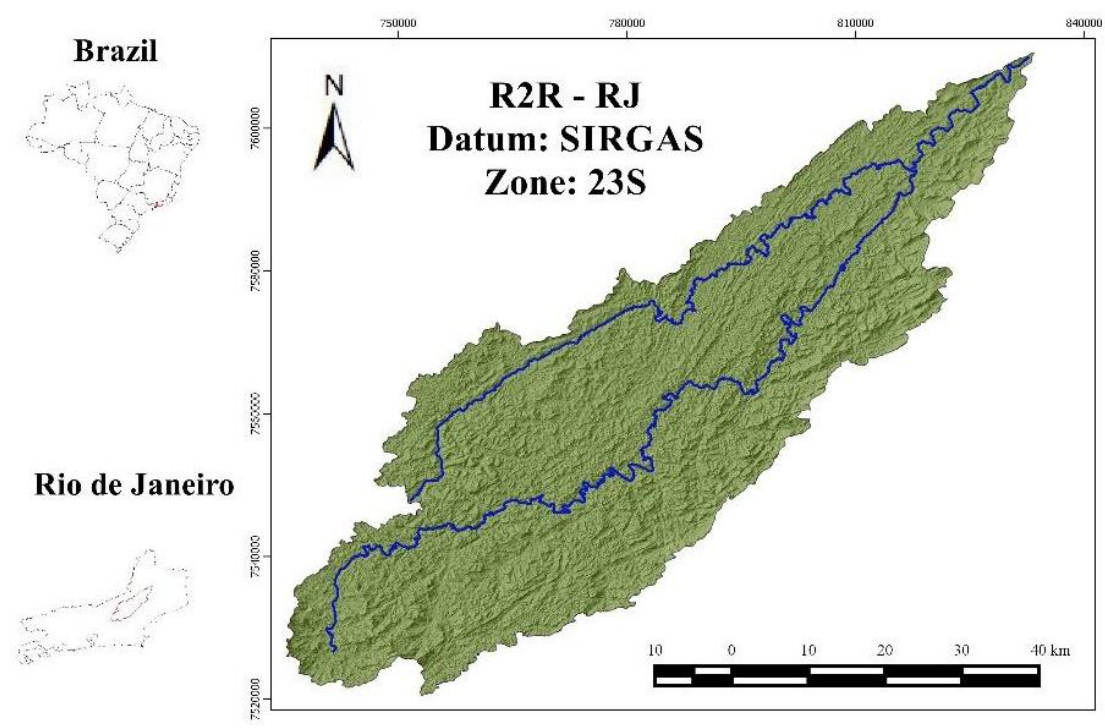

Figure 1. Dois Rios River Basin (R2R) - Rio de Janeiro State, Brazil.

\subsection{Hydrologically Consistent Digital Elevation Model}

The Hydrologically Consistent Digital Elevation Model (HCDEM) was generated from the continuous vectorial cartographic base of the state of Rio de Janeiro, on a scale of 1:25,000 (IBGE, 2012), using the procedures performed by ArcGIS 10.2 software (Figure 2).

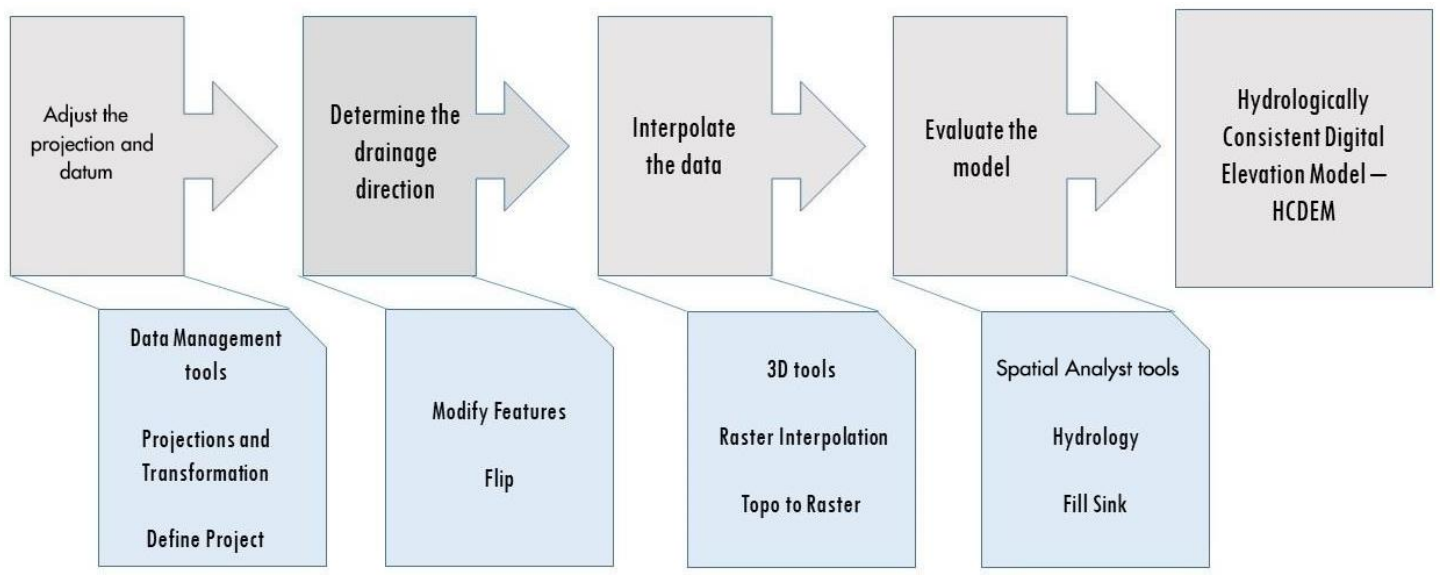

Figure 2. Procedures employed for determining the Hydrologically Consistent Digital Elevation Model (HCDEM).

\subsection{Geospatial Attributes and Ecosystemic Services}

Ecosystemic services related to water resources are factors of the physical environment itself combined with the biotic environment, which, when functioning in an integrated fashion, 
can improve the water supply in hydrographic basins. In order to delimit, characterize, group and select the floodplains with similar propensities for producing ecosystemic services which maximize the perennialization of water in the R2R catchment basin, the following indicators were established: $i$ ) Regions with the highest pluviometric indexes; ii) Identification of their micro basins (capture zones) based on morphometric attributes (area, circularity index, orientation and plane of the curve); and iii) Selection of floodplains with the greatest capacity for retaining water based on the parameters of area, circularity index, altitude and land use and occupation.

The minimum precipitation which was considered was $1500 \mathrm{~mm} / \mathrm{year}$. This was spatialized with help from the Clip tool in the QGIS 2.18 software, with an isohyetal map as database (CPRM, 2001). This part of the catchment basin was sectorized according to its micro basins of up to $3^{\text {rd }}$ order, utilizing the Basin tool of the ArcGIS 10.2 software, available in Spatial Analyst Tools $\rightarrow$ Hydrology, as well as the circularity index (CI) (Equation 1) (Cardoso et al., 2006).

$$
C I=\frac{(12.57 \times A)}{P^{2}}
$$

In which:

$$
\begin{aligned}
& \mathrm{CI}=\text { Circularity Index (adimensional); } \\
& \mathrm{A}=\text { Drainage Area }\left(\mathrm{m}^{2}\right) \\
& \mathrm{P}=\text { Perimeter }(\mathrm{m})
\end{aligned}
$$

In the ArcGIS 10.2 software, the slope areas were calculated according to their orientation (Aspect, in Spatial Analyst Tools $\rightarrow$ Surface), then the results were vectorized (from Raster to Polygon, in Conversion Tools). After this procedure, the area of each stretch of the slope was calculated according to its orientation (Calculate Geometry $\rightarrow$ Area). The plane of the curve was obtained using the Curvature command in Spatial Analyst Tools $\rightarrow$ Surface, followed by vectorization of the results (from Raster to Polygon, in Conversion Tools). Using the results of this vectorization, the area of each stretch of the slope was calculated according to its orientation (Calculate Geometry $\rightarrow$ Area). Based on these parameters, the micro basins were grouped according to the hydrographic attributes they offer and their similarities. The Cluster analysis of the SPSS 15.0 software was used to define the group with the best hydrological attributes.

The hydrological model for identifying areas saturated with water - "Topographic Wetness Index" (TWI) - was extracted from the SAGA GIS 2.0.8 HCDEM software (Olaya and Conrad, 2009), using the tool Terrain Analysis > Hydrology > Topographic Indices. The division of these areas was established by the cut-off line in the TWI by the adimensional value 5.85 . These data were later validated during in situ field visits in $10 \%$ of the areas studied. They were then verified using Landsat images with a resolution of 15 meters.

The hydrological attributes of water retention analyzed in the floodplains were: $i$ ) Area; $i$ ) Circularity Index; iii) Altitude; and iv) Land Use and Coverage. To obtain the area and circularity index of these floodplains, the commands described previously were used. Altitude was obtained by using Elevation - Obtain Elevation, in the QGIS 2.18 software, clicking on the highest point, where the floodplain ends.

Soil use and coverage for the floodplains were obtained by using the cutout of the vector provided by the IBGE, on the scale of 1:25,000, which, superimposed on the areas of the floodplains, identify land use, plant coverage and the existence of stone outcroppings in the areas surrounding the floodplains. Subsequently, these floodplains were grouped by similarity of hydrological attributes, using the Cluster analysis of the SPSS 15.0 software and selecting the group of floodplains with the best hydrological attributes for water retention.

\section{IPABH}

Rev. Ambient. Água vol. 14 n. 2, e2296 - Taubaté 2019 


\section{RESULTS AND DISCUSSION}

The R2R basin $\left(3159 \mathrm{~km}^{2}\right)$ is influenced by the leeward side of the Serra do Mar mountains, and contains 220.000 inhabitants, 09 municipalities, 42 micro basins and 7467 floodplains. The distribution of rainfall varies between 1000 and $2800 \mathrm{~mm} /$ year, with the management of the part with rainfall higher than $1500 \mathrm{~mm}$ /year being of strategic priority, where the use of the catchment basins is an important form of managing their ecosystemic services, both for capturing horizontal precipitation which is a hidden component of the total humidity on the slopes during the rainy seasons, and for storing and maintaining the flow during the dry seasons through the action of the floodplains in the smaller areas which belong to the higher parts of the basin. Thus, the strategic areas which generate water benefits for the entire catchment basin can be defined.

\subsection{Areas with High Rainfall}

The orographic and environmental condition of the catchment basin shows that the greatest volumes of rainfall (between 1500 and $2800 \mathrm{~mm} /$ year) occur in only $13.1 \%$ of its area (Figure 3 ), and that these locations must be treated with the highest priority. Below these locations, an increase in temperature and a decrease in the volume of precipitation occur, increasing loss due to evapotranspiration.

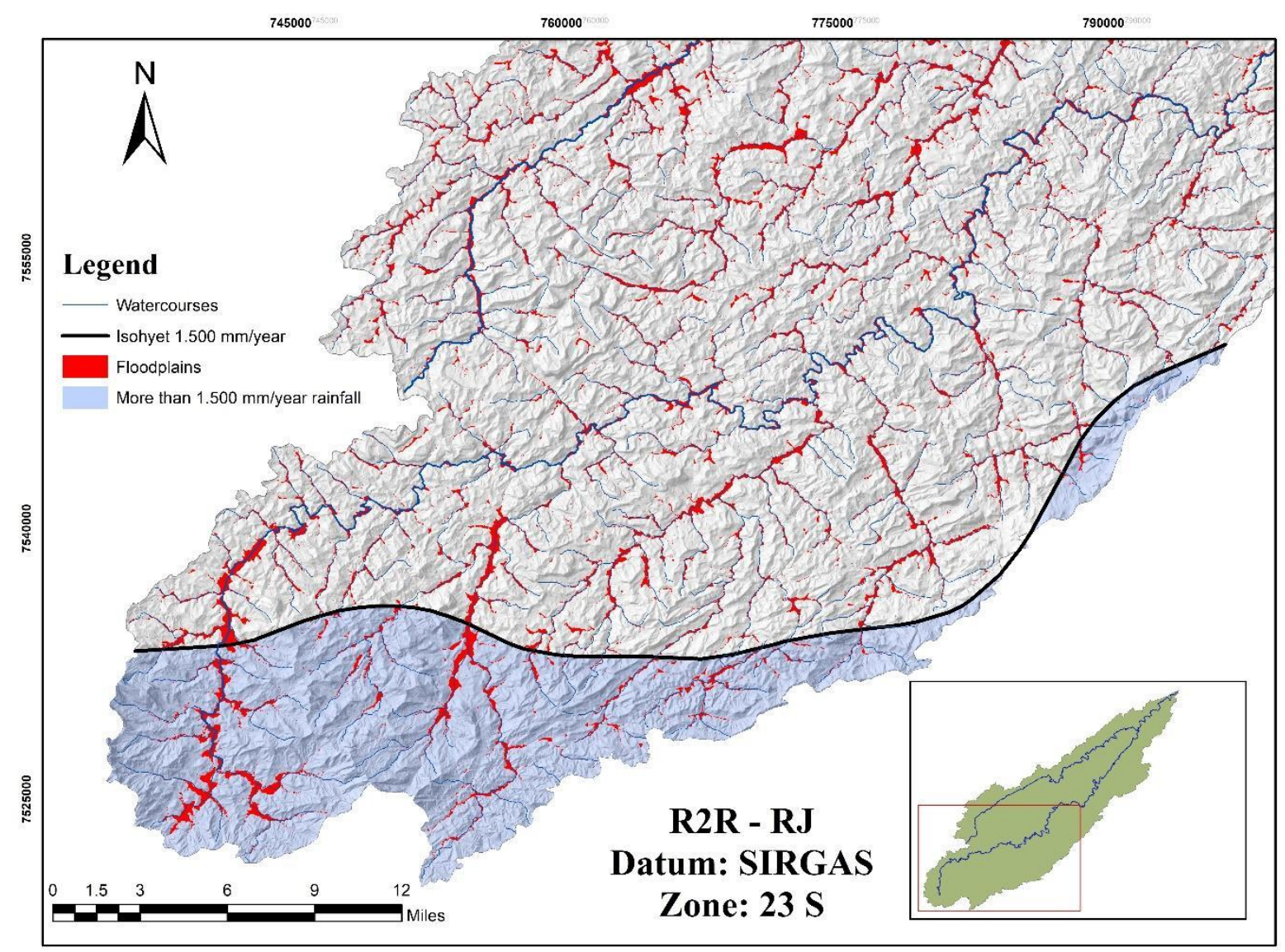

Figure 3. Floodplains located in the area with annual rainfall greater than $1.500 \mathrm{~mm}$.

\subsection{Grouping micro basins}

Excessive rainfall can also be a source of degradation, if the landscape is not environmentally adjusted, as can be seen by the frequent landslides and floods and prolonged droughts in the low areas (CPRM, 2001; Corrêa and Costa, 2016). The combination of the water 
entering the catchment basins and the storage of that water in the floodplains is fundamental 1 for sustainable water supply projects, for both agriculture and the population.

During this study, 42 micro basins of up to the third order were encountered which presented a potential for producing relevant ecosystemic services related with water resources. Area is a morphometric characteristic which can be related to the maximum discharge (Horton, 1945), depending on the types and characteristics of the soils. The average size of the micro basins (320-1835 ha) determines the prioritization of the smaller basins, both because these show greater hydrological sensitivity to the uses to which they are subject, and because they contain fewer users, thus facilitating regional agreements with the objective of adopting conservationist practices. The smaller basins offer greater options for the management of their slopes and other areas (Tonello et al., 2006). Another fact which attests to the greater interactivity between characteristics of their physical environment and the management of these basins is the influence of a greater number of factors, such as the effects of water storage in floodplains in large catchment basins, with less pronounced flood peaks (Borsato and Martone, 2004).

The circularity index of these 42 micro basins was an average of 0.48 , ranging from 0.43 to 0.53 , similar to the results encountered by Oliveira et al. (2010). CI values greater than 0.51 indicate a tendency for the basin to be circular (Schumm, 1956), thus favoring flooding processes; lower values indicate elongated forms, suggesting shorter water paths from the slopes, reducing the concentration time and draining the water more rapidly. Cardoso et al. (2006) state that the greater the circularity of a catchment basin, the greater the tendency for intense rain to occur simultaneously throughout its entire extension, which concentrates a large volume of water in the principle tributary. Tonello et al. (2006) add that the elongated form of the catchment basin - defined by the index number farthest from unity - causes a lower concentration of runoff and less risk of flooding. Therefore, the micro basins with the highest CI were selected.

The predominance of convex slopes (an average of 50.2\%) was detected in relation to concave plane curvature $(39.8 \%)$, which demonstrates the character of these slopes for dispersing water (Dragut and Blaschke, 2006). The micro basins selected present a higher average of slopes with a concave plane curvature $(40.4 \%)$ than the others $(39.2 \%)$. The concave plane curvature is related to a concentration of water, increasing the potential for mass movements (flow of debris and landslides) (Silveira et al., 2013), and thus being a factor associated with erosive processes (Sartori et al., 2005). The concentration of water indicates a delay in the runoff of that water.

The predominance of slopes oriented to leeward (an average of 44.3\%) was apparent, with only 7 micro basins showing a predominance of windward orientation. Micro basins with a higher percentage of windward slopes $(34.4 \%)$ in comparison to the others $(29.6 \%)$ were selected, because due to the steep terrain, there is a difference in the precipitation received between windward slopes and leeward slopes, considering the masses of moist air to which they are exposed (Dragut and Blaschke, 2016).

After the identification and selection of the micro basins with the best environmental attributes for water production (larger areas, higher CIs, concave plane curvature and slopes oriented to windward), it was possible to identify, group and select the floodplains situated within these micro basins which present geospatial environmental attributes which favor the supply of hydrological ecosystemic services. Grouping them according to similar capacities offers classifications to the hydrological processes in 4 groups (Table 1).

Groups III (12 micro basins) and IV (5 micro basins) include areas with slopes oriented to permit them to capture humidity $(35.33 \%$ e $33.42 \%$ of their areas, respectively) and a concave plane curvature ( $40.5 \%$ and $40.2 \%$, respectively), as well as possessing larger surface areas, conditioning factors which increase the rainfall they receive and induce a higher concentration 
of humidity per area, physical attributes capable of conferring a higher probability of offering ecosystemic services.

Table 1. Groups of micro basins, units per group and average values of morphometric variables.

\begin{tabular}{lccccc}
\hline Micro- Basin Group & $\mathbf{n}$ & Average Area (hectares) & $\begin{array}{c}\text { Southern Orientation } \\
\left(\mathbf{S O / S E / S )} \mathbf{~}^{(\%)}\right.\end{array}$ & $\begin{array}{c}\text { Concave Plane } \\
\text { Curvatura (\%) }\end{array}$ & CI $^{2}$ \\
\hline Group I & 16 & 635.1 & 28.9 & 40.0 & 0.50 \\
Group II & 09 & 320.0 & 30.4 & 38.4 & 0.43 \\
Group III & 12 & 1061.6 & 35.3 & 40.5 & 0.47 \\
Group IV & 05 & 1835.3 & 33.4 & 40.2 & 0.53 \\
\hline Total & 42 & 963.0 & 32.0 & 39.8 & 0.48 \\
\hline
\end{tabular}

$\mathrm{n}$ - Number of Units (micro basins).

1 - Oriented to Southwest, Southeast or South.

2 - Circularity Index.

Groups III (12 micro basins) and IV (5 micro basins) include areas with slopes oriented to permit them to capture humidity (35.33\% e $33.42 \%$ of their areas, respectively) and a concave plane curvature ( $40.5 \%$ and $40.2 \%$, respectively), as well as possessing larger surface areas, conditioning factors which increase the rainfall they receive and induce a higher concentration of humidity per area, physical attributes capable of conferring a higher probability of offering ecosystemic services.

\subsection{Grouping of Floodplains}

In the R2R Hydrographic Basin, 7467 floodplains cover $241.91 \mathrm{~km}^{2}$, which represents $6.58 \%$ of the basin's total area. This value is similar to that observed in other literature (Hamilton, 2002). In the basin of the main river (Paraíba do Sul), the floodplains are larger and fewer in number, totaling 1.16\% of the surface area (Baptista et al., 2014). This information shows their high potential for producing ecosystemic services related to water regularization. Of these floodplains, 1071 are located in the region with precipitation greater than $1500 \mathrm{~mm} /$ year and within the 42 micro basins with the highest priority in terms of territorial management, based on the differentiated supply of environmental attributes which can offer distinct environmental services, corresponding to $20.37 \mathrm{~km}^{2}$ or $8.42 \%$ of the area of all the floodplains in the basin (Figure 3).

Of the floodplains located in the region with rainfall of more than $1500 \mathrm{~mm} / \mathrm{year}, 729$ $(68.06 \%)$ are located in the 17 micro basins whose morphometric attributes confer the highest probability of producing water through their ecosystemic services (Groups III and IV). These micro basins are steep, with a high number of floodplains and heterogeneous geospatial attributes, which, to a certain degree, justify the integration and interdependence of their effects for guaranteeing the continuity of water production.

The average area of 1.5 hectares is not significant, because of the high variability (ranging from 0.008 to 119.6 ha). This high variability was also observed in relation to the circularity index ( 0.07 to 0.98 ). The larger floodplains present low circularity indices, affecting the rate at which water is liberated and contributing to its regularization. It can be observed that floodplains along the channel of the Paraíba do Sul River follow this trend, with CIs ranging from 0.001 to 0.52 (Baptista et al., 2014), with no significant difference being noted between this characteristic of the main river and that of the tributaries of the Paraíba do Sul, confirming the replicability of the study.

Of these 729 floodplains, $42.1 \%$ present forest coverage. Agriculture and pastures compose another $42.8 \%$ of that coverage. Even though nearly half of the floodplains are 
anthropized by farming activities, these areas are still subject to alterations of their land use which can be reversed through renaturation activities. Only $14.9 \%$ of the areas are occupied by residences or infrastructure (consolidated uses). This value is near to that encountered in the floodplains of the Paraíba do Sul River (18.94\%), showing that, in general, the floodplains present a low level of urbanization, with part of their hydrological functions still being preserved. This fact, associated with adequate planning for the orderly advance of urbanization in the floodplains, may enhance services for the renaturation of their hydrological functions (Baptista et al., 2014). Urbanization impairs the hydrological functions and ecosystemic services provided by floodplains (Baptista et al., 2017), as it leaves the soil compacted and impermeable, and also impedes the connection with the river channel. The low proportion of occupied areas demonstrates that it is still possible to adequate the land uses demanded by society with the offer of ecosystemic services, permitting the implantation of renaturation measures to improve the performance of areas with high water production (Baptista e Valcarcel, 2018).

As mentioned earlier, by using the Cluster function, 4 groups of floodplains with similar environmental attributes were formed (Table 2). The fourth group stands out from the rest because of its capacity for retaining water, with a total of 498 floodplains with high potential for water reservation, if the necessary conservational measures are utilized.

Table 2. Groups of floodplains, units per group and averages of the variables analyzed.

\begin{tabular}{lccccc}
\hline & N & AA $(\mathbf{h a})$ & ACI & UAP $(\boldsymbol{\%})$ & AAl $(\mathbf{m})$ \\
\hline Group A & 213 & 0.9 & 0.63 & 92.2 & 1014.9 \\
Group B & 3 & 91.2 & 0.12 & 86.5 & 981.6 \\
Group C & 15 & 30.9 & 0.21 & 49.0 & 984.1 \\
Group D & 498 & 0.4 & 0.60 & 1.9 & 1112.1 \\
\hline Total & 729 & 30.8 & 0.40 & 57.4 & 1023.2 \\
\hline
\end{tabular}

$\mathrm{N}$ - Number of Units (Floodplains); AA - Average Area in hectares; ACI Average Circularity Index; UAP - Percentage of the area occupied by Urbanization, Agriculture and Pasture; AAl - Average Altitude in meters.

Considering the high percentage of the surface area occupied by Urbanization, Agriculture and Pasture, Groups A and B do not possess the ability to administer water resources, because the anthropic uses of the floodplains have diminished their capacity for water storage and their ability to offer ecosystemic services (Baptista et al., 2017). In these areas, the elevated levels of anthropization have prioritized strategic solutions, although actions for water renaturation should be reinforced, with a view toward increasing the delay time for filling those floodplains which show a high potential for flooding and water regularization within Group A (a high ACI).

While half of the floodplains in Group $\mathrm{C}$ are not anthropized, this group has a low ACI. According to Schumm (1956), CI values greater than 0.51 indicate that the basin tends to be circular, favoring flooding processes (higher flood peaks); values lower than 0.51 suggest that the basin tends to be elongated, contributing to the drainage process and the escape of water resources from the hydrographic basin. Considering the analogous reasoning between hydrological units and floodplains, this means that the floodplains of Group $\mathrm{C}$ have a tendency to disperse water, similar to the findings of Oliveira et al. (2010).

Group D has a high ACI, which indicates a lower capacity for superficial runoff, and consequently an increase in water retention. The higher altitude guarantees that precipitation normally exceeds evapotranspiration, providing enough water to maintain a constant supply to the aquifers which are responsible for the springs that feed the watercourses (Cardoso et al., 2006). Low occupation rates increase the infiltration and water storage capacity (Vanzela et al.,

\section{IPABH}

Rev. Ambient. Água vol. 14 n. 2, e2296 - Taubaté 2019 
2010) and contribute to low-cost management. These factors permit this group of floodplains, which correspond to $0.01 \%$ of the total area of all the floodplains and $0.0006 \%$ of the total area of the catchment basin, to be selected as the best areas in the catchment basin in terms of potential for offering ecosystemic services for water retention.

\subsection{The Supply of Ecosystemic Services}

The $13.1 \%$ of the basin with rainfall between 1500 and $2800 \mathrm{~mm} /$ year has a greater horizontal interception, which may add up to $44 \%$ to the pluviometric precipitation (Barboza et al., 2015) in its $6.93 \%$ of the territory total of the basin in Groups III and IV, which has an environmental advantage related to a greater propensity for receiving both pluviometric rainfall and occult precipitation. This volume of water entering the subsystems of the slopes and the floodplains, if managed according to conservationist techniques and/or reinforced through measures for the renaturation of water functions, can produce benefits for water regulation in the areas located downriver which present a water deficit. This effect also reduces flooding and its consequences in both urban and rural spaces (Baptista and Valcarcel, 2018). The ecosystemic services for water regularization observed in the 7467 floodplains $\left(241.91 \mathrm{~km}^{2}\right)$, which represents $6.58 \%$ of the basin's total area, affect the recharge and discharge. These are the main ecosystemic services related with water regularization (Schindler et al., 2016).

A variety of renaturating actions have been utilized around the world, including the hydromorphological restoration in the Danube River (Riquier et al., 2015) and the revitalization of wetlands in the Anacostia (Baldwin, 2004), Isar (Binder, 2010) and Rheine rivers (Lamers, 2006). These measures require the integration of technical, socio-economic and legal approaches (González et al., 2017). The mapping of floodplains with high potential for the renaturation of water functions is fundamental for increasing the supply of water in terms of both quantity and quality for the population located downriver. This mapping and the identification of the peculiar characteristics of each location are essential to the success of such measures.

Physical and biological measures are important for potentializing ecosystemic services. An example of a physical measure is the opening of recharge areas at sites far from the river channel (Hein et al., 2016), providing great benefits at a low cost because they increase the water storage capacity of the floodplains. Biological measures such as selective cutting of trees (instead of the clear cutting of forests), maintenance of woody vegetation and prioritization in planting species with appropriate root systems are efficient in maintaining the hydrological functions of floodplains, integrated with social demands (González et al., 2017). As a renaturalization proposal for the middle stretch of the Ebro River, the creation of a "river territory" was suggested, aimed at creating conditions for the river to resume its conditions of navigability (Ollero, 2010). Other measures based on a combination of physical, physical-biological and biological works could also be implemented (Schindler et al., 2014).

Even by selecting strategic floodplains, these do not function in a homogeneous way throughout their entire extension. Their main processes must be studied in order to separate them into sectors with distinct hydrological capabilities, based on their specific geomorphological characteristics, aimed at achieving functional synergy and increasing their water capture and storage functions, thus permitting the development of techniques which can be directed towards the better administration of water resources.

\section{CONCLUSIONS}

In order to contribute to territorial planning and the optimal utilization of the ecosystemic services of floodplains, groups of micro basins (I, II, III and IV) were first formed based on favorable environmental attributes (slopes oriented to permit them to capture humidity and concave plane curvature to retain that humidity) so that the best locations for receiving 
pluviometric precipitation (rainfall between 1500 and $2800 \mathrm{~mm} / \mathrm{ano}$ ) and occult precipitation could be defined, according to the aerial corridors which transport humidity and the locations with frontal exposure to the geographical entrances of those corridors into the region, determined by the lowest passes in the high Serra do Mar mountain range. In the groups with adequate attributes and the highest rate of capture of rainfall (Groups III and IV), the floodplains were identified and grouped according to the highest propensity for storing water and contributing to water regularization, forming 4 groups (A, B, C and D). Group D presented the greatest potential for water retention, with the highest average characteristics of surface area, circularity index and altitude, and the lowest occupation rates, for the implantation of measures for renaturizing the hydrological functions, with the objective of increasing the offer of ecosystemic services downriver and promoting water regularization in the catchment basin.

The precipitation concentrated in the headwaters of hydrographic basins $(13.1 \%$ of the total area, in the case of the $\mathrm{R} 2 \mathrm{R}$ region) is an important element to be considered in planning land use focused on the management of the ecosystemic services capable of interfering in the production and administration of water. Of the 7467 floodplains in the R2R catchment basin, only 498 (corresponding to $0.0006 \%$ of the total surface area) present optimum conditions for promoting water regulation through the management of their distinctive supply of ecosystemic services, which can benefit the entire catchment basin. These criteria for safeguarding their hydrological functions may affect the collection of water in the micro basins and the water regulation in the floodplains. These results will be materialized in the form of water regulation and continuity of flow, notably in the dry periods, improving the quality and quantity of water in the catchment basin. These focal actions offer greater responses with less investment. Any planning activities which pursue the sustainability of the water system should take these areas into consideration, because they are strategic for guaranteeing perennial flow in the springs and providing water for all the different activities being developed within the catchment basin.

Considering the repressed demands for an adequate water supply, the potential ecosystemic services offered by floodplains and the scarcity of information about these environments, the development of studies which permit deeper knowledge of the sectors within those floodplains, which offer different ecosystemic services and different functional relationships with the physical surroundings, is of extreme importance.

\section{ACKNOWLEDGEMENTS}

We wish to thank the Municipal Government of Nova Friburgo for having permitted time off from other functions to perform these studies. Also, the UFRRJ/PPGCAF (the PostGraduate Program for Environmental and Forestry Sciences of the Federal Rural University of the State of Rio de Janeiro) for permitting this opportunity for learning, and the CAPES (the Coordination for Perfection of University-Level Personnel, of the Brazilian Ministry of Education) for providing the necessary support.

\section{REFERENCES}

AGEVAP. Plano de recursos hídricos da bacia do rio Paraíba do Sul: Diagnóstico dos recursos hídricos - relatório Final. Laboratório de Hidrologia e Estudos de Meio Ambiente, 2006. (Relatório Contratual R-7). Available in: www.ceivap.org.br/downloads/PSR-010-R0.pdf. Access: June 042018.

BALDWIN, A. H. Restoring complex vegetation in urban settings: The case of tidal freshwater $\begin{array}{llllll}\text { marshes. Urban } & 2004 .\end{array}$ https://doi.org/10.1023/B:UECO.0000036265.86125.34 
BAPTISTA, M. N.; VALCARCEL, R. Renaturalizing Floodplains. Journal of Water Resource and Protection, v. 10, n. 05, p. 533- 537, 2018. https://dx.doi.org/10.4236/jwarp.2018.105029

BAPTISTA, M. N.; VALCARCEL, R.; MATEUS, F. A.; MEDEIROS, W. S.; ANDRADE, F. C. Impact of Urbanization on the Hydrodynamics of a Water Table in a Floodplain with High Potential for Renaturation. Water Resources Management, v. 31, n. 13, p. 40914102, 2017. http://dx.doi.org/10.1007/s11269-017-1731-5

BAPTISTA, M. N.; VALCARCEL, R.; MAYA, V.; CANTO, F. Floodplains for the Renaturalization of Hydrologic Functions: A Case Study of the Paraíba do Sul River Basin, Brazil. Water Resources Management, v. 28, n. 13, p. 4781-4793, 2014. https://dx.doi.org/10.1007/s11269-014-0775-z

BARBOZA, R. S.; VALCARCEL, R.; SANTOS, E. O.; PEREIRA, C. R. Air basins of Rio de Janeiro - Brazil. Journal of Water Resource and Protection, v. 7, p. 781-791, 2015. http://dx.doi.org/10.4236/jwarp.2015.710064

BINDER, W. The Restoration of the Isar South of Munich. Wasserwirtschaft, v. 100, p. 1519, 2010.

BORSATO, F. H.; MARTONI, A. M. Estudo da fisiografia das bacias hidrográficas urbanas no município de Maringá, estado do Paraná. Acta Scientiarum, v. 26, n. 2, p. 273-285, 2004. http://dx.doi.org/10.4025/actascihumansoc.v26i2.1391

CARDOSO, A. C.; DIAS, H. C. T.; SOARES, C. P. B.; MARTINS, S. V. Caracterização morfométrica da bacia hidrográfica do rio Debossan, Nova Friburgo-RJ. Revista Árvore, v. 30, n. 2, p. 241-248, 2006. http://dx.doi.org/10.1590/S0100-67622006000200011

CORRÊA, C. A.; COSTA, A. J. T. Usos na Bacia Hidrográfica do Paraíba do Sul: considerações acerca da escassez de água, inundações e Área de Preservação Permanente no trecho fluminense. Revista de Geografia, v. 33, n. 3, 2016.

CORTINES, E.; PEREIRA, A. L.; DOS SANTOS, P. R. O.; SANTOS, G. L.; VALCARCEL, R. Vegetação arbórea em vertentes com orientação norte e sul na Floresta Montana, Nova Friburgo-RJ. Floresta e Ambiente, v. 18, n. 4, p. 428-437, 2011. http://dx.doi.org/10.4322/floram.2011.062

CPRM. Mapa de isoietas do estado do Rio de Janeiro. Brasília, 2001. 1 map. Scale 1:500000. 1 CD-ROM.

DRAGUT, L.; BLASCHKE, T. Automated Classification of Landform Elements Using ObjectBased Image Analysis. Geomorphology, v. 81, p. 330-344, 2006. https://dx.doi.org/10.1016/j.geomorph.2006.04.013

GONZÁLEZ, E.; FELIPE-LUCIA, M.; BOURGEOIS, B.; BOZ, B.; NILSSON, C.; PALMER, G.; SHER, A. Integrative conservation of riparian zones. Biological Conservation, v. 211, p. 20-29, 2017. https://dx.doi.org/10.1016/j.biocon.2016.10.035

HAMILTON, S. Comparison of inundation patterns among major South American floodplains. Journal of Geophysical Research, v. 107, p. 1-14, 2002. https://dx.doi.org/10.1029/2000JD000306

HEIN, T.; SCHWARZ, U.; HABERSACK, H.; NICHERSU, I.; PREINER, S.; WILLBY, N.; WEIGELHOFER, G. Current status and restoration options for floodplains along the Danube River. Science of the Total Environment, v. 543, p. 778-790, 2016. https://dx.doi.org/10.1016/j.scitotenv.2015.09.073 
HORTON, R. E. Erosional development of streams their drainage basins: hidrophysical approach to quantitative morphology. Geological Society of America Bulletin, v. 56, p. 275-370, 1945. https://dx.doi.org/10.1016/j.landusepol.2014.10.015

IBGE. Manual Técnico de Vegetação Brasileira. 2. ed. Rio de Janeiro, 2012. 276p.

LAMERS, L.; LOERB, R.; ANTHEUNISSE, A.; MILETTO, M.; LUCASSEN, E. Biogeochemical constraints on the ecological rehabilitation of wetland vegetation in river floodplains. Hydrobiologia, v. 565, p. 165-186, 2006. http://dx.doi.org/10.1007/s10750005-1912-8

OLAYA, V.; CONRAD, O. Geomorphometry in SAGA. Developments in Soil Science, v. 33, p. 293-308, 2009. https://dx.doi.org/10.1016/S0166-2481(08)00012-3

OLIVEIRA, P. T. S. DE; SOBRINHO, T. A.; STEFFEN, J. L.; RODRIGUES, D. B. B. Caracterização morfométrica de bacias hidrográficas através de dados SRTM. Revista Brasileira de Engenharia Agrícola e Ambiental, v. 14, n. 8, p. 819-825, 2010.

OLLERO, A. Channel changes and floodplain management in the meandering middle Ebro River, Spain. Geomorphology, v. 117, n. 3-4, p. 247-260, 2010. https://dx.doi.org/10.1016/j.geomorph.2009.01.015

OSWALD, C. J.; RICHARDSON, M. C.; BRANFIREUN, B. A. Water storage dynamics and runoff response of a boreal Shield headwater catchment. Hydrological Processes, v. 25, n. 19, p. 3042-3060, 2011. https://dx.doi.org/10.1002/hyp.8036

REINHARDT, C.; BÖLSCHER, J.; SCHULTE, A.; WENZEL, R. Decentralised water retention along the river channels in a mesoscale catchment in south-eastern Germany. Physics and Chemistry of the Earth, Parts A/B/C, v. 36, n. 7, p. 309-318, 2011. https://dx.doi.org/10.1016/j.pce.2011.01.012

RIQUIER, J.; PIÉGAY, H.; MICHALKOVÁ, M. Hydromorphological conditions in eighteen restored floodplain channels of a large river: linking patterns to processes. Freshwater Biology, v. 60, p. 1085-1103, 2015. http://dx.doi.org/10.1111/fwb.12411

SARTORI, A.; LOMBARDI NETO, F.; GENOVEZ, A. M. Classificação hidrológica de solos brasileiros para a estimativa da chuva excedente com o método do Serviço de Conservação do Solo dos Estados Unidos Parte 1: Classificação. Revista Brasileira de Recursos Hídricos, v. 10, n. 4, p. 05-18, 2005.

SCHINDLER, S.; O’NEILL, F. H.; BIRO, M.; DAMM, C.; GASSO, V.; KANKA, R.; SLUIS, T. V.; KRUG, A.; LAUWAARS, S. G.; SEBESVARI, Z.; PUSCH, M.; BARANOVSKY, B.; EHLERT, T.; NEUKIRCHEN, B.;MARTIN, J. R.; EULLER, K.; MAUERHOFER, V.; WRBKA, T. Multifunctional floodplain management and biodiversity effects: a knowledge synthesis for six European countries. Biodiversity Conservation, v. 25, p. 1349-1382, 2016. http://dx.doi.org/10.1007/s10531-016-1129-3

SCHINDLER, S.; SEBESVARI, Z.; DAMM, C.; EULLER, K.; MAUERHOFER, V.; SCHNEIDERGRUBER, A.; BIRÓ, M.; ESSL, F.; KANKA, R.; LAUWAARS, S.; SCHULZ-ZUNKEL, C.; VAN DER SLUIS, T.; KROPIK, M.; GASSO, V.; KRUG, A.; PUSCH, M.; ZULKA, K.; LAZOWSKI, W.; HAINZ-RENETZEDER, C.; HENLE, K.; WRBKA, T. Multifunctionality of floodplain landscapes: Relating management options to ecosystem services. Landscape Ecology, v. 29, n. 2, p. 229-244, 2014. http://dx.doi.org/10.1007/s10980-014-9989-y 
SCHUMM, S. A. Evolution of drainage systems and slopes in badlands at Perth Amboy, New Jersey. Geological Society of America Bulletin, v. 67, n. 5, p. 597-646, 1956. https://dx.doi.org/10.1130/0016-7606(1956)67[597:EODSAS]2.0.CO;2

SILVEIRA, C. T.; FIORI, A. P.; FERREIRA, A. M.; DE GÓIS, J. R.; DE MIO, G.; SILVEIRA, R. M. P; MASSULINI, N. E. B.; LEONARDI, T. M. H. Emprego de atributos topográficos no mapeamento da susceptibilidade a processos geoambientais na bacia do rio Jacareí, Paraná. Sociedade \& Natureza, v. 25, n. 3, 2013.

TONELlO, K. C.; DIAS, H. C. T., SOUZA, A. L.; RIBEIRO, C. A. A. S.; LEITE, F. P. Morfometria da bacia hidrográfica da Cachoeira das Pombas, Guanhães-MG. Revista Árvore, v. 30, n. 5, p. 849-857, 2006.

VANZELA, L.; HERNANDEZ, F. B.; FRANCO, R. A. Influência do uso e ocupação do solo nos recursos hídricos do Córrego Três Barras, Marinópolis. Revista Brasileira de Engenharia Agrícola e Ambiental, v. 14, n. 1, 2010. 